\title{
AIDS vaccine 'needs focused effort' as drug firms back off research
}

Paris. A world-wide consensus is emerging that the scientific community urgently needs to increase its efforts to develop an AIDS vaccine, partly to fill the gap left by the retreat of drug companies from pursuing this goal. Such a conclusion is being fuelled by the growing awareness that only a vaccine can curtail the explosion of AIDS in developing countries.

The need for a new, targeted vaccine strategy is, for example, expected to be the main thrust of a report on AIDS vaccine research at the US National Institutes of Health (NIH), to be released shortly by the agency's Office of AIDS Research (OAR) as part of a wider review by the office of AIDS research at the agency.

Broadly similar recommendations are thought likely to emerge from discussions of a 'task force' on vaccine research and development set up by the European commissioner for research, Edith Cresson.

The US report is widely expected to recommend that NIH should go beyond its traditional role of funding basic research and also become what Dani Bolognesi, from Duke University, the review's rapporteur, describes as a "discovery engine for the concepts for the design of the vaccine", aimed at bringing vaccines to the stage at which industry might regain interest.

"There is a sense that we have to do something radically different, with the major worry that otherwise companies will not become interested," says Bolognesi.

Moreover, while drug companies are traditionally reluctant to invest in any form of vaccine development - which carries high costs, low profits and big risks of costly legal suits should accidents occur - their current analysis of the state of AIDS vaccine research is particularly bleak.

"The traditional methods of vaccine development don't work with HIV," says one spokesperson at Glaxo-Wellcome. "It's back to the [research] drawing board." Similarly, Maurice Hilleman, a director of the Merck Institute for Therapeutic Research in West Point, Pennsylvania, claims that companies are reluctant to invest money because "there is currently no basis for the development of an AIDS vaccine".

Some blame this reluctance on the way AIDS research has developed. "The field

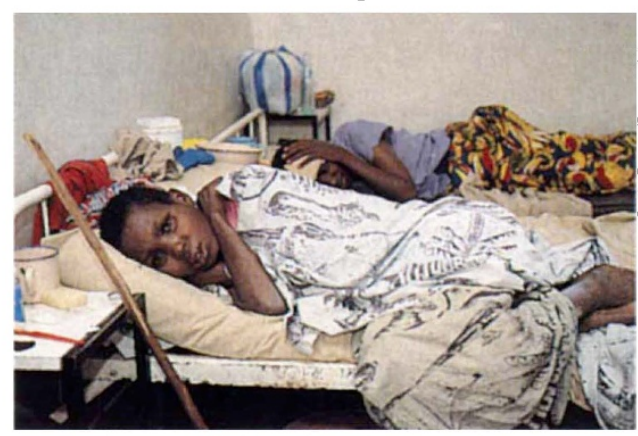

Rising tide: an AIDS patient in Kigali, Rwanda.

has been driven by a discipline [molecular biology] and not by good science," claims one leading US vaccine researcher, arguing that this has led to the pursuit of approaches that ignore the pathogenesis of HIV.

He describes the current crop of subunit vaccines, such as those based on gp120 and gp160 antigens, as "the closest thing to insanity". Not only are they designed to reduce viral load - while HIV has high turnover and mutation rates - but they also suppress the cytotoxic T-cell response that clears infected cells and the virus they contain. The latter response is now considered to be an essential component of any effective vaccine.

The OAR review panel is said to have accepted such criticisms. As a result, the

\section{Swiss role in EU research will remain limited}

Basel. An agreement between Switzerland and the European Commission, which would have allowed Swiss scientists to play a more active role in the commission's Fourth Framework Programme, will not be signed this year because of the Swiss government's refusal to comply with the commission's demand that it open its labour market to all citizens of the European Union (EU).

The two issues are both part of a complex package of proposed agreements on relations between Switzerland and the EU that has been under negotiation since Switzerland abandoned plans to apply for membership of the European Economic
Area, as a prelude to EU membership, in 1992 (see Nature 373,$462 ; 1995$ ).

Last week's deadlock in the negotiations means that Swiss scientists will not be apply to apply for EC research money as project leaders from next year, as they had hoped. Under the present agreement, scientists can only take part in the framework projects led by non-Swiss scientists, and cannot become members of decision-making programme committees.

But Tim Guldimann, a member of the group that advises the Swiss government on science and research policy, says that he remains optimistic that agreement could be reached by 1997. Oliver Klaffke panel is expected to recommend abandoning the approach of "simply pushing ahead and testing as you go along", according to William Paul, director of OAR. Instead, it is likely to propose a broader and more fundamental approach, building up a body of knowledge that would remain useful even if the next generation of vaccines should fail.

Similarly, the review is expected to urge $\mathrm{NIH}$ to set up a targeted programme. This would include preclinical studies to test vaccine concepts but would stop short of industrial development. Such research is not possible at present, says one vaccine researcher, claiming that funding research through investigator-initiated grants creates a "bunch of little islands" which are failing to accumulate the collective knowledge needed for industrial development.

Paul agrees that a more coordinated approach is needed. But he argues that this must not be at the expense of basic research on AIDS. Bolognesi also says that NIH needs to provide extra money for such programmes, in particular to improve the quality of much research by attracting leading scientists, and to make vaccine research a priority.

Bolognesi also points out that no systematic study has been carried out to determine which animal models are the most predictive of a good vaccine in humans. At present, models are not answering the right questions, he says; "we are mainly guessing".

Another AIDS researcher claims that the expected recommendations of the OAR review would represent a break with work over the past decade, during which AIDS vaccine research has been too distracted by, for example, the debate about whether to conduct clinical trials of subunit vaccines.

Similarly, Jean-Paul Levy, director of the French National Agency for AIDS Research, describes Phase III trials as an "absurdity" at the moment, given the lack of basic knowledge. "We are unsure if we will ever be able to get a vaccine for this virus, which is different to any virus for which we have ever created a vaccine," says Levy.

Not all are convinced that developing an AIDS vaccine means abandoning the traditional approach to vaccine development, however. "If we had been waiting to have all the immunological answers before we made the measles or polio vaccines, we would be still waiting," says Donald Francis of Genentech in San Francisco.

Francis argues that Genentech's gp120 candidate vaccine, which may enter trials in Thailand next year, has already protected chimpanzees and is safe, and that it is 
therefore worth testing. "The next-generation vaccines have not yet protected chimps," he adds. But one official at Genentech's parent company Hoffmann La-Roche says he is sure that "Genentech is well informed that gp120 is not very interesting for the future". Similarly, apart from the Thailand trials, Genentech's management is believed by many researchers to have pulled the plug on both the gp120 programme and AIDS vaccine research in general.

But most scientists seem to agree that it is time to explore a wider choice of research avenues. They argue, for example, that not enough attention has been given to so-called therapeutic vaccines which might attenuate infection to a level that could prevent the onset of AIDS, or transmission of the virus. Others argue that work on attenuated viruses merits much greater attention, despite the concerns about their safety.

In contrast, there has been growing criticism of the way that much AIDS vaccine research is directed at the B subtypes of HIV that are common in infections in the developed world. The OAR review is expected to recommend refocusing AIDS vaccine research on the HIV subtypes common in the developing world, where "a fire is raging", says one AIDS researcher.

The preliminary conclusions of the OAR reviews are echoed by an official at the European Commission, who claims that HIV vaccine research lacks both coordination and funding. The research directorate has recently created a task force on vaccines - headed by Bruno Hansen, formerly of Novo Nordisk - with other commission directorates. This will coordinate existing vaccine research within the European Union's Framework research programmes, and is seeking ECU100 million (US\$ 133.44 million) over the three years 1996-1998 for a scries of new programmes.

Another proposal comes from Seth Berkley from the Rockefeller Foundation in New York, who is trying to raise $\$ 600$ million over seven years to set up an International AIDS Vaccine Initiative. This would fund existing laboratories rather than create new structures, says Berkley.

But others remain sceptical about whether the scientific community can replace industry's role in vaccine development. Levy, for example, argues that in the absence of adequate animal models, Phase I trials - which are needed not to test vaccines, he emphasizes, but to obtain information - require industrial support.

France is home to the company Pasteur Mérieux Sérums et Vaccins - now a subsidiary of Rhône-Poulenc Rorer - which is one of the few large companies taking a broad interest in HIV vaccine research. The company is already developing one of the first so-called second-generation 'prime boost' vaccines, made of an avipox virus genetically engineered to produce subunit proteins, and designed to give both a humoral and cellular response. Declan Butler

\section{Black scientist faces inquiry at South African university}

Cape Town. A black South African scientist with an international reputation in immunology, head-hunted from Britain to a senior post at the University of the Witwatersrand (Wits), has become the centre of a fierce controversy about his fitness for office, amid speculation over his possible candidacy as the university's next vice-chancellor.

The university has set up a tribunal to look into allegations by 13 senior academics against William Makgoba, one of its deputy vice-chancellors. In a letter to the current vice-chancellor, Robert Charlton, the academics challenged statements made by Makgoba in various versions of his curriculum vitae, and allege that he has failed adequately to carry out the responsibilities of his current job.

The academics also claim that a series of public Makgoba: tribunal will statements made

by Makgoba about the university over the past year have undermined - and are thus incompatible with - the proper performance of these responsibilities.

Makgoba in turn has dismissed the allegations against him as an "orchestrated campaign of vilification and disinformation". He has declined an invitation to discuss the matter with Charlton, arguing that the outcome of such a meeting would be a foregone conclusion, and asking that the matter be handled on a formal basis.

Makgoba graduated from the University of Natal Medical School in 1976, and left South Africa shortly afterwards to pursue his studies overseas. He appeared to have impeccable credentials for his new post at Wits, to which he was appointed last year; at the time of his appointment, for example, he was a senior lecturer in immunology at the Royal London Postgraduate Medical School in the United Kingdom.

But last month, scarcely a year after he assumed office, a group of nine deans and four senior professors at Wits wrote a letter of complaint to Charlton. The allegations against Makgoba include falsely claiming membership of both the American Association of Immunology and the British Transplantation Society, and receiving a grant of $£ 80,000$ (US $\$ 128,000$ ) from the Nuffield Trust while at Oxford's John Radcliffe School of Medicine between 1979 and 1983.

Makgoba also wrongly claimed that a paper he co-authored in the journal Immunology Today in 1988 was the most- cited article in the life sciences in the following year. In the light of these charges, Charlton sent a letter inviting Makgoba and his legal representative to a meeting on 2 November, saying that this meeting was intended to satisfy him that "the allegations lacked weight and substance, and that there would be no need for further proceedings".

But Makgoba, who could not be contacted for comment, has said that he prefers to clear his name in front of a full committee of inquiry. "The thirtecn excellent academics got it so wrong it is incredible," he told the Johannesburg Sunday Times. "In conducting research by using Procrustean methods they will follow the fate of Procrustes," he said, adding that the Greek mythological figure - who used force to impose conformity - was himself eventually killed.

Some of Makgoba's critics have themselves come under fire for their tactics. Charles van Onselen, for example, a social historian, has been criticized for the methods he used to investigate Makgoba's claim that he was the first African graduate to obtain a distinction and a certificate of merit in medicine at the University of Natal. Rather than requesting the information directly, Onselen learned that no such award had been made by writing to the university registrar on the pretext of obtaining assistance with what he called "a rather esoteric inquiry for a piece of social history".

Last week, representatives of the Wits Black Staff Forum and the South African National Students' Congress accused a "white clique" of waging a vendetta against Makgoba and called for Charlton's resignation on the grounds that his handling of the matter and statements have polarized the university on racial lines. Makaziwe Mandela, an executive member of the forum, and daughter of President Nelson Mandela, claimed the university was trying to get rid of Makgoba because he had demonstrated his independence and intelligence.

But Charlton, who retires in 1997 , has been trying to play down the racial dimension. He has responded to critics such as Mandela by claiming that, while everything in South Africa is represented in racial terms, the complaints against Makgoba can be investigated objectively. "If he had been white, the complaints would have been the same," he added.

A three-person tribunal has been set up by the university to look into the affair. Lord Flowers, the former vice-chancellor of the University of London, and Walter Kamba, dean of law at the University of Namibia, have already agreed to be members. The third person has yet to be appointed.

Michael Cherry 